\title{
Analisis Postur Kerja Karyawan Kantor di Departemen Produksi Menggunakan Metode Rapid Office Strain Assesment (ROSA) (Studi Kasus : PT. Indah Kiat Pulp \& Paper tbk)
}

\author{
Zayyinul Hayati Zen, Agus Mulyadi \\ Program Studi Teknik Industri Fakultas Teknik Universitas Muhammadiyah Riau \\ Jalan Tuanku Tambusai Ujung Pekanbaru \\ E-mail : zayyinulhayati@umri.ac.id
}

\begin{abstract}
Abstrak
PT. Indah Kiat Pulp \& Paper adalah salah satu perusahaan nasional yang bergerak dibidang produksi Pulp dan kertas. Perusahaan yang terletak di perawang ini memanfaatkan teknologi sebagai salah satu alat yang dapat mempermudah pekerjaan seperti komputer. Penelitian ini berfokus pada seksi Paper Machine\#6 yang pekerjanya bekerja di ruangan. Pekerja selalu menggunakan komputer lebih dari 8 jam/hari. Penelitian awal dengan cara menyebarkan kuesioner Standart Nordic Questionnaire (SNQ) untuk mengetahui keluhan yang dirasakan karyawan. Dari kuesioner banyak pekerja yang merasakan sakit pada punggung, pantat, pinggang, paha dan pergelangan tangan. Keluhan tersebut dapat diminimalkan dengan cara mengetahui dan mengidentifikasi postur kerja pada karyawan dalam menggunakan komputer dengan menggunakan metode Rapid Office Strain Assesment (ROSA). ROSA merupakan salah satu metode khusus ergonomi perkantoran, dimana penilaiannya dirancang untuk mengukur resiko yang terkait dengan penggunaan komputer. Dengan metode ini maka dapat diketahui apakah postur kerja pada karyawan kantor PT. Indah Kiat Pulp \& Paper Tbk masih dibatas yang dianggap aman. Hasil penilaian postur kerja dengan ROSA yaitu postur kerja beresiko, pada keadaan tersebut jika dilakukan terus menerus tanpa ada perbaikan maka dapat meyebabkan cidera yang berdampak pada kinerja dan produktivitas karyawan. Oleh sebab itu perlu direkomendasikan ke perusahaan yang bersangkutan dengan melakukan perbaikan. perbaikan yang dilakukan untuk mengurangi tingkat resiko yang dirasakan dengan cara perbaikan fasilitas kerja yang digunakan dengan standar ergonomi dan penggunaan jam isitirahat dengan peregangan otot atau relaksasi.
\end{abstract}

Kata kunci : Ergonomi, Postur Kerja, ROSA

\section{Pendahuluan}

PT. Indah Kiat Pulp \& Paper Tbk (PT.IKPP) adalah salah satu perusahaan nasional yang bergerak dibidang produksi Pulp dan kertas. Lokasi perusahaan terletak di kota Perawang karena berdekatan dengan supply bahan baku utama yang berasal dari perusahaan PT. Arara Abadi. Selain itu, lokasi yang berdekatan dengan sungai Siak sebagai sarana transportasi jalur air menjadi salah satu alasan berdirinya PT. IKPP di Perawang .

PT. IKPP memiliki 106 divisi dan 284 seksi dalam lingkungan pekerjaanya. seperti bagian administrasi, marketing, produksi, maintenace, warehouse, safety \& health dan personalia. Setiap pekerja memiliki lokasi kerja masing-masing tergantung tanggung jawab, seperti maintenace yang bekerja di lapangan atau workshop. Jam kerja yang berlaku adalah 8 jam/hari selama 5 hari dalam seminggu dan memungkinkan lebih jika diperlukan overtime atau lembur.

Penelitian dilakukan di departemen produksi paper machine 6 (PPM\#6). PPM\#6 memiliki 2 lantai, lantai pertama terdiri atas tangki-tangki yang digunakan sebagai penampung bahan baku dan proses kimia pembuatan kertas. Sedangkan lantai ke 2 terdiri dari 2 bagian, dimana bagian pertama diisi dengan mesin kertas dan bagian ke 2 terdiri dari kantor produksi seperti DCS (ruang kontrol), ruang winder, ruang reel, administrasi dan kantor setiap PIC dari mesin. penelitian di PPM\#6 berada di bagian DCS yang bekerja didepan komputer untuk mengontrol sistem produksi kertas.

Selama penelitian, dilakukan observasi dan wawancara terhadap pekerja kantor yang berjumlah 10 orang pekerja yang bekerja di lantai 2. Dari observasi dan wawancara banyak pekerja yang mengeluhkan nyeri pada leher, punggung, kaki dan 
tangan. Karena hal tersebut disebarkan kuesioner mengenai keluhan yang dirasakan terhadap pekerja kantor tersebut. Kuesioner dibuat untuk 10 orang pekerja kantor yang selalu bekerja di depan komputer.

Dari kuesioner yang telah disebarkan keluhan terbanyak yang dialami oleh pekerja kantor yaitu paha, pergelangan bagian bawah (kaki) dan punggung juga dialami karena fasilitas kerja yang kurang ergonomis, selain itu keluhan sakit pada pantat, betis serta pada bagian pergelangan tangan dan leher. Keluhan tersebut dapat diminimalkan dengan cara mengetahui dan mengidentifikasi postur kerja. Identifikasi digunakan untuk mengetahui sumber penyebab utama atas keluhan yang dirasakan pekerja kantor sehingga dapat dilakukan perbaikan. Oleh sebab itu perlu dilakukan analisis terhadap pekerja kantor dengan menggunakan metode Rapid Office Strain Assesment (ROSA) untuk mengurangi keluhan yang dirasakan.

ROSA merupakan salah satu metode khusus ergonomi perkantoran, dimana penilaiannya dirancang untuk mengukur resiko yang terkait dengan penggunaan Komputer, serta untuk menetapkan tingkat tindakan perubahan berdasarkan laporan dari ketidaknyamanan pekerja. Dengan menggunakan metode ini maka dapat diketahui apakah postur kerja pekerja kantor masih dibatas yang dianggap aman. Jika dari analisis menunjukkan level resiko yang berbahaya maka diperlukan perbaikan. Perbaikan yang dilakukan untuk mengurangi tingkat resiko yang dirasakan dengan cara perbaikan fasilitas kerja yang digunakan dengan standar ergonomi dan penggunaan jam istirahat dengan peregangan otot atau relaksasi.

\section{Methodologi}

Penelitian dilakukan pada bagian kantor DCS di seksi Paper Machine\#6 (PPM\#6) PT. indah kiat pulp \& paper Tbk Perawang. Objek yang diamati adalah karyawan kantor yang bekerja dalam ruangan dimana pekerjaannya selalu berhubungan dengan computer., lama karyawan kantor bekerja dalam sehari yaitu 8 jam dan memungkinkan lebih jika dilemburkan.

Data yang digunakan dalam penelitian ini adalah data yang diperoleh dari penyebaran kuesioner dan pengamatan langsung (foto dan video) karyawan kantor. Kuesioner standart Nordic questionnaire (SNQ) disebarkan untuk mengidentifikasi keluhan yang dirasakan karyawan kantor akibat bekerja secara terus menerus bekerja di depan computer.

Selanjutnya adalah melakukan analisis penilaian postur kerja untuk semua aktivitas yang dilakukan pada bagian perkantoran dengan menggunakan metode Rapid Office Strain Assesment (ROSA).

\section{Hasil dan Pembahasan}

Berikut kegiatan yang berlangsung selama karyawan kantor bekerja di PT. Indah Kiat Pulp \& Paper Tbk.

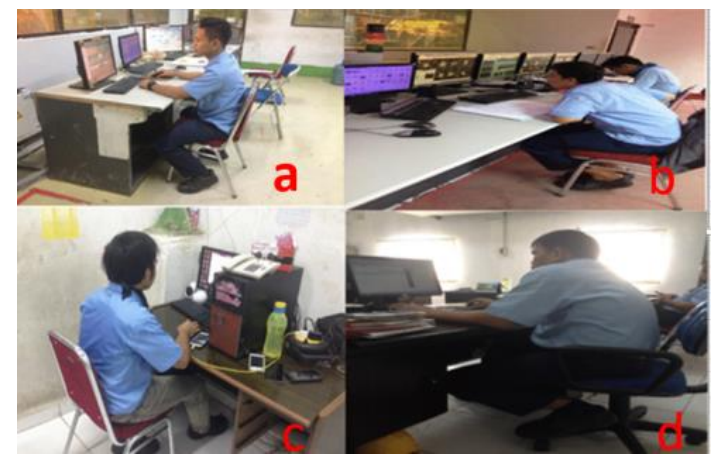

Gambar 1. Kondisi Riil Di PT. Indah Kiat Pulp \& Paper Tbk

Pada gambar tersebut terlihat kondisi operator dan kondisi dari fasilitas yang disediakan masih belum menggunakan prinsip ergonomi, seperti tidak adanya sandaran tangan, sandaran punggung yang terlalu kecil serta tidak dapat di adjustable. Selain itu posisi kaki yang membentuk $<90^{\circ}$ dan membungkuk karena posisi monitor yang lumayan jauh lalu tidak adanya penompang leher dan roda yang dapat memudahkan operator berpindah dari satu komputer ke komputer yang lain.

\subsection{Identifikasi Keluhan Pekerja Menggunakan Standart Nordic Questionnaire (SNQ)}

Untuk mengetahui keluhan yang dirasakan karyawan kantor maka perlu dilakukan identifikasi dengan cara penyebaran kuesioner SNQ. Melalui kuesioner ini dapat diketahui bagian otot yang mengalami keluhan berdasarkan tingkat keluhan mulai dari tidak sakit (0), agak sakit (1), sakit (2) dan sangat sakit (3).

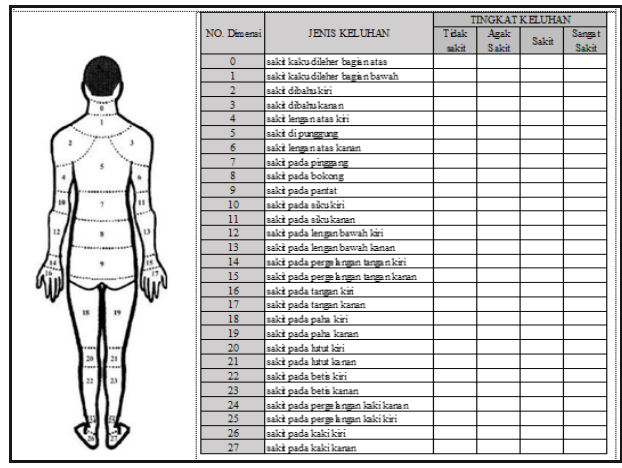

Gambar 2. Standart Nordic Questionnaire (SNQ) 
Dari hasil penyebaran kuesioner SNQ bahwa karyawan kantor merasakan sakit tertinggi pada bagian punggung, pantat, pinggang, paha dan pergelangan tangan.

\subsection{Penilaian Postur Kerja Menggunakan Metode ROSA}

a. Data Ketinggian Kursi

Penilaian postur kerja menggunakan metode ROSA terhadap 10 orang karyawan kantor di PT. Indah Kiat Pulp \& Paper Tbk yang dibagi dalam 3 section, sehingga diperoleh nilai sebagai berikut:

\subsubsection{Section A}

Tabel 1.

Rekapitulasi data ketinggian kursi

\begin{tabular}{clcll}
\hline No & \multicolumn{1}{c}{ Pekerja } & $\begin{array}{c}\text { Sudut Kaki yang } \\
\text { Terbentuk }\end{array}$ & Posisi Kaki dengan Meja & $\begin{array}{c}\text { Pengaturan } \\
\text { Ketinggian Kursi }\end{array}$ \\
\hline 1 & DCS operator & $<90^{\circ}$ & kaki tidak menyentuh meja & non-adjustable \\
2 & Reel operator & $<90^{\circ}$ & kaki menyentuh meja & non-adjustable \\
3 & Winder 1 Operator & $<90^{\circ}$ & kaki tidak menyentuh meja & non-adjustable \\
4 & Winder 2 Operator & $<90^{\circ}$ & kaki tidak menyentuh meja & non-adjustable \\
5 & Administrasi production & $<90^{\circ}$ & kaki menyentuh meja & Adjustable \\
6 & PIC chemical \& stock & $<90^{\circ}$ & kaki tidak menyentuh meja & non-adjustable \\
7 & PIC paper machine & $<90^{\circ}$ & kaki menyentuh meja & Adjustable \\
8 & PIC work planner \& safety & $>90^{\circ}$ & kaki menyentuh meja & Adjustable \\
9 & PIC warehouse & $<90^{\circ}$ & kaki tidak menyentuh meja & non-adjustable \\
10 & PIC winder & $<90^{\circ}$ & kaki menyentuh meja & Adjustable \\
\hline
\end{tabular}

b. Data Kedalaman Kursi

Tabel 2.

Rekapitulasi Data Kedalaman Kursi

\begin{tabular}{|c|c|c|c|c|}
\hline No & Pekerja & Jarak Ujung Kaki dengan Lutut & Pengaturan Kedalaman Kursi & Skor \\
\hline 1 & DCS operator & lebih dari 3 inci & non-adjustable & 3 \\
\hline 2 & Reel operator & sekitar 3 inci & non-adjustable & 2 \\
\hline 3 & Winder 1 Operator & lebih dari 3 inci & non-adjustable & 3 \\
\hline 4 & Winder 2 Operator & lebih dari 3 inci & non-adjustable & 3 \\
\hline 5 & Administrasi production & lebih dari 3 inci & non-adjustable & 3 \\
\hline 6 & PIC chemical \& stock & sekitar 3 inci & non-adjustable & 2 \\
\hline 7 & PIC paper machine & kurang dari 3 inci & non-adjustable & 3 \\
\hline 8 & PIC work planner \& safety & lebih dari 3 inci & non-adjustable & 3 \\
\hline 9 & PIC warehouse & lebih dari 3 inci & non-adjustable & 3 \\
\hline 10 & PIC winder & lebih dari 3 inci & non-adjustable & 3 \\
\hline
\end{tabular}

SURYA TEKNIKA Vol. 5 No. 2, Desember 2017 : 46 - 56 
ISSN: 2354-6751

c. Data Sandaran Tangan

Tabel 3.

Rekapitulasi Data Sandaran Tangan

\begin{tabular}{clcccc}
\hline No & \multicolumn{1}{c}{ Pekerja } & Posisi Sandaran Tangan & $\begin{array}{c}\text { Lebar Sandaran } \\
\text { Tangan }\end{array}$ & $\begin{array}{c}\text { Pengaturan Sandaran } \\
\text { Tangan }\end{array}$ & Skor \\
\hline 1 & DCS operator & terlalu tinggi & tidak ada & non-adjustable & 3 \\
2 & Reel operator & terlalu tinggi & tidak ada & non-adjustable & 3 \\
3 & Winder 1 Operator & terlalu tinggi & tidak ada & non-adjustable & 3 \\
4 & Winder 2 Operator & terlalu tinggi & tidak ada & non-adjustable & 3 \\
5 & Administrasi production & terlalu tinggi & sesuai & non-adjustable & 3 \\
6 & PIC chemical \& stock & sesuai & sesuai & non-adjustable & 2 \\
7 & PIC paper machine & sesuai & sesuai & non-adjustable & 2 \\
8 & PIC work planner \& safety & sesuai & sesuai & non-adjustable & 2 \\
9 & PIC warehouse & terlalu tinggi & sesuai & non-adjustable & 3 \\
10 & PIC winder & sesuai & sesuai & non-adjustable & 2 \\
\hline
\end{tabular}

d. Data Sandaran Punggung

Tabel 4.

Rekapitulasi Data Sandaran Punggung

\begin{tabular}{clcccc}
\hline No & \multicolumn{1}{c}{ Pekerja } & $\begin{array}{c}\text { Posisi Sandaran } \\
\text { Punggung }\end{array}$ & $\begin{array}{c}\text { Posisi Permukaan } \\
\text { Meja Kerja }\end{array}$ & $\begin{array}{c}\text { Pengaturan Sandaran } \\
\text { Punggung }\end{array}$ & Skor \\
\hline 1 & DCS operator & memadai & tidak tinggi & non-adjustable & 2 \\
2 & Reel operator & memadai & tidak tinggi & non-adjustable & 2 \\
3 & Winder 1 Operator & tidak digunakan & tidak tinggi & non-adjustable & 3 \\
4 & Winder 2 Operator & memadai & terlalu tinggi & non-adjustable & 4 \\
5 & Administrasi production & tidak digunakan & tidak tinggi & non-adjustable & 3 \\
6 & PIC chemical \& stock & tidak digunakan & tidak tinggi & non-adjustable & 3 \\
7 & PIC paper machine & tidak digunakan & tidak tinggi & non-adjustable & 3 \\
8 & PIC work planner \& safety & tidak digunakan & terlalu tinggi & non-adjustable & 4 \\
9 & PIC warehouse & tidak digunakan & tidak tinggi & non-adjustable & 3 \\
10 & PIC winder & memadai & tidak tinggi & non-adjustable & 2 \\
\hline
\end{tabular}

\subsubsection{Section B}

a. Data Penggunaan Monitor

Tabel 5.

Rekapitulasi Data Penggunaan Monitor

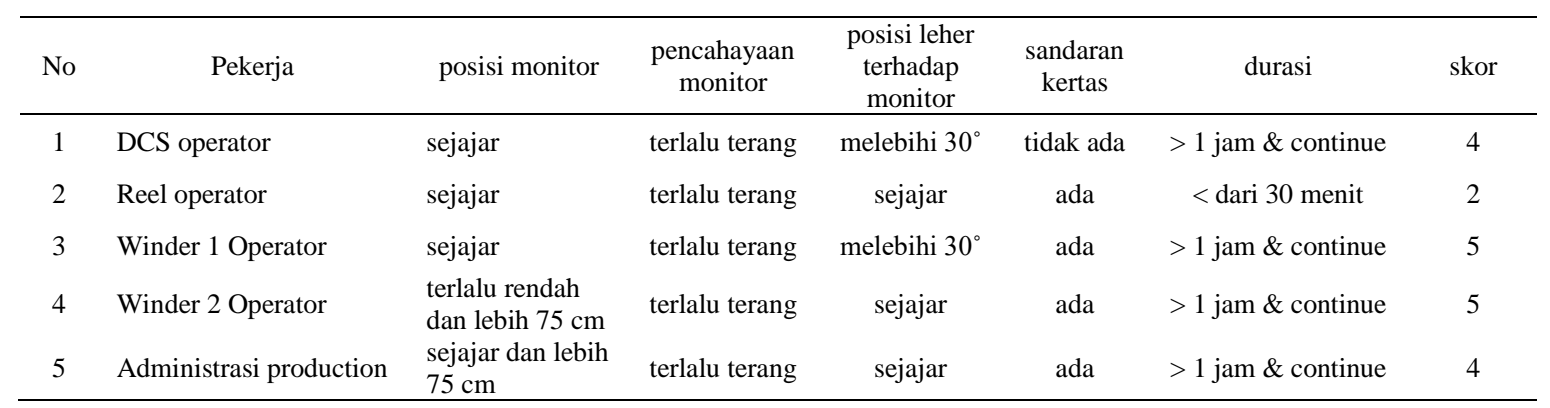

SURYA TEKNIKA Vol. 5 No. 2, Desember $2017: 46$ - 56 
ISSN: 2354-6751

\begin{tabular}{|c|c|c|c|c|c|c|c|}
\hline 6 & PIC chemical \& stock & $\begin{array}{l}\text { terlalu rendah } \\
\text { dan lebih } 75 \mathrm{~cm}\end{array}$ & terlalu terang & sejajar & tidak ada & $>1$ jam \& continue & 6 \\
\hline 7 & PIC paper machine & $\begin{array}{l}\text { terlalu rendah } \\
\text { dan lebih } 75 \mathrm{~cm}\end{array}$ & terlalu terang & sejajar & ada & $>1$ jam \& continue & 5 \\
\hline 8 & $\begin{array}{l}\text { PIC work planner \& } \\
\text { safety }\end{array}$ & sejajar & terlalu terang & sejajar & tidak ada & $>1$ jam \& continue & 4 \\
\hline 9 & PIC warehouse & terlalu rendah & terlalu terang & sejajar & tidak ada & $>1$ jam \& continue & 5 \\
\hline 10 & PIC winder & terlalu rendah & terlalu terang & sejajar & ada & $>1$ jam \& continue & 5 \\
\hline
\end{tabular}

b. Data Penggunaan telephone

Tabel 6.

Rekapitulasi Data Penggunaan telephone

\begin{tabular}{cllcc}
\hline No & \multicolumn{1}{c}{ Pekerja } & Posisi Telephone & Durasi & Skor \\
\hline 1 & DCS operator & jarak telephone lebih dari $30 \mathrm{~cm}$ & kurang dari 30 menit & 1 \\
2 & Reel operator & jarak telephone lebih dari $30 \mathrm{~cm}$ & kurang dari 30 menit & 1 \\
3 & Winder 1 Operator & jarak telephone lebih dari $30 \mathrm{~cm}$ & kurang dari 30 menit & 1 \\
4 & Winder 2 Operator & jarak telephone lebih dari $30 \mathrm{~cm}$ & kurang dari 30 menit & 1 \\
5 & Administrasi production & jarak telephone lebih dari $30 \mathrm{~cm}$ & kurang dari 30 menit & 1 \\
6 & PIC chemical \& stock & jarak telephone lebih dari $30 \mathrm{~cm}$ & kurang dari 30 menit & 1 \\
7 & PIC paper machine & jarak telephone lebih dari $30 \mathrm{~cm}$ & kurang dari 30 menit & 1 \\
8 & PIC work planner \& safety & jarak telephone lebih dari $30 \mathrm{~cm}$ & kurang dari 30 menit & 1 \\
9 & PIC warehouse & jarak telephone lebih dari $30 \mathrm{~cm}$ & kurang dari 30 menit & 1 \\
10 & PIC winder & jarak telephone lebih dari $30 \mathrm{~cm}$ & kurang dari 30 menit & 1 \\
\hline
\end{tabular}

\subsubsection{Section $\mathrm{C}$}

a. Data Penggunaan Mouse

Tabel 7.

Rekapitulasi Data Penggunaan Mouse

\begin{tabular}{|c|c|c|c|c|c|}
\hline No & Pekerja & Posisi Mouse & Letak Mouse & Durasi & Skor \\
\hline 1 & DCS operator & mudah dijangkau & satu meja dengan keyboard & lebih dari 1 jam dan continue & 2 \\
\hline 2 & Reel operator & mudah dijangkau & satu meja dengan keyboard & kurang dari 30 menit continue & 0 \\
\hline 3 & Winder 1 Operator & mudah dijangkau & satu meja dengan keyboard & lebih dari 1 jam dan continue & 2 \\
\hline 4 & Winder 2 Operator & mudah dijangkau & satu meja dengan keyboard & lebih dari 1 jam dan continue & 2 \\
\hline 5 & Administrasi production & mudah dijangkau & satu meja dengan keyboard & lebih dari 1 jam dan continue & 2 \\
\hline 6 & PIC chemical \& stock & mudah dijangkau \& kecil & satu meja dengan keyboard & lebih dari 1 jam dan continue & 3 \\
\hline 7 & PIC paper machine & mudah dijangkau & satu meja dengan keyboard & lebih dari 1 jam dan continue & 2 \\
\hline 8 & PIC work planner \& safety & mudah dijangkau \& kecil & satu meja dengan keyboard & lebih dari 1 jam dan continue & 3 \\
\hline 9 & PIC warehouse & mudah dijangkau \& kecil & satu meja dengan keyboard & lebih dari 1 jam dan continue & 3 \\
\hline 10 & PIC winder & mudah dijangkau & satu meja dengan keyboard & kurang dari 30 menit continue & 1 \\
\hline
\end{tabular}


ISSN: 2354-6751

b. Data Penggunaan keyboard

Tabel 8.

Rekapitulasi Data Penggunaan keyboard

\begin{tabular}{clccc}
\hline No & \multicolumn{1}{c}{ Pekerja } & $\begin{array}{c}\text { Sudut yang } \\
\text { Terbentuk }\end{array}$ & Posisi Keyboard & Durasi \\
\hline 1 & DCS operator & $>15^{\circ}$ & tidak tinggi & lebih dari 1 jam dan continue \\
2 & Reel operator & $>15^{\circ}$ & tidak tinggi & kurang dari 30 menit continue \\
3 & Winder 1 Operator & $>15^{\circ}$ & tidak tinggi & lebih dari 1 jam dan continue \\
4 & Winder 2 Operator & $>15^{\circ}$ & tidak tinggi & lebih dari 1 jam dan continue \\
5 & Administrasi production & $>15^{\circ}$ & tidak tinggi & lebih dari 1 jam dan continue \\
6 & PIC chemical \& stock & $>15^{\circ}$ & tidak tinggi & lebih dari 1 jam dan continue \\
7 & PIC paper machine & $>15^{\circ}$ & tidak tinggi & lebih dari 1 jam dan continue \\
8 & PIC work planner \& safety & $>15^{\circ}$ & tidak tinggi & lebih dari 1 jam dan continue \\
9 & PIC warehouse & $<15^{\circ}$ & tidak tinggi \& gunakan 2 tangan & lebih dari 1 jam dan continue \\
10 & PIC winder & $>15^{\circ}$ & tidak tinggi & kurang dari 30 menit continue \\
\hline
\end{tabular}

\subsection{Penentuan nilai akhir Menggunakan Metode ROSA}

Dalam menentukan nilai akhir menggunakan metode ROSA, data yang telah dikumpulkan dikelompokkan menjadi 3 bagian yaitu :

1. Section A (chair) : data bagian ini berasal dari perhitungan ketinggian kursi dijumlahkan kedalaman kursi dan sandaran tangan dijumlahkan dengan sandaran punggung.

2. Section B (monitor and telephone) : data bagian ini berasal dari perhitungan monitor dan telephone.

3. Section $C$ (mouse and keyboard) : data bagian ini berasal dari perhitungan mouse dan keyboard.

Sebelum penentuan nilai akhir ada beberapa tahapan yang akan dilakukan yaitu penentuan peripherals and monitor score lalu membandingkan nilai tersebut dengan section A yang telah dibandingkan. Berikut adalah tahapan menentukan nilai skor dengan metode ROSA:

\subsubsection{Menentukan Nilai Skor Bagian A}

Menentukan nilai skor section A dengan cara membandingkan ketinggian kursi + kedalaman kursi dengan sandaran tangan + sandaran punggung menggunakan log up table. Berikut perhitungan penentuan nilai akhir section A dari 10 pekerja kantor seksi PPM\#6.
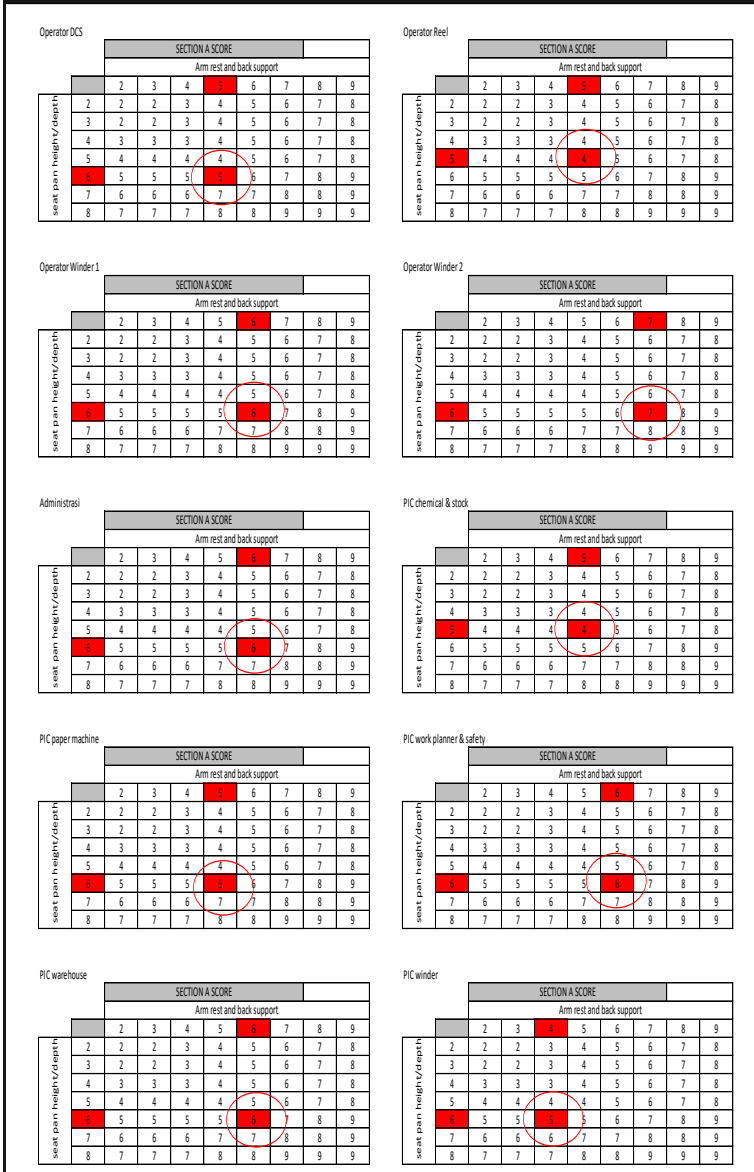

Gambar 3. Perhitungan Nilai Akhir Section A 


\subsubsection{Menentukan Nilai Skor Bagian B}

Dalam menentukan nilai akhir section $B$ yaitu dengan cara membandingkan skor yang diperoleh dari monitor dan telephone dengan menggunakan log up table.

Gambar 2 menunjukkan perhitungan tahapan alam penentua nilai akhir section $\mathrm{B}$ dari 10 pekerja kantor di departemen produksi.
3.3.3 Menentukan Nilai Skor Bagian C

Dalam menentukan nilai skor pada section $C$ diperoleh dengan cara membandingkan skor keyboard dan mouse dari form ROSA yang telah diperoleh sebelumnya. Perbandingan tersebut menggunakan log up table. Berikut adalah perhitungan terhadap 10 pekerja kantor yang berada di departemen produksi.
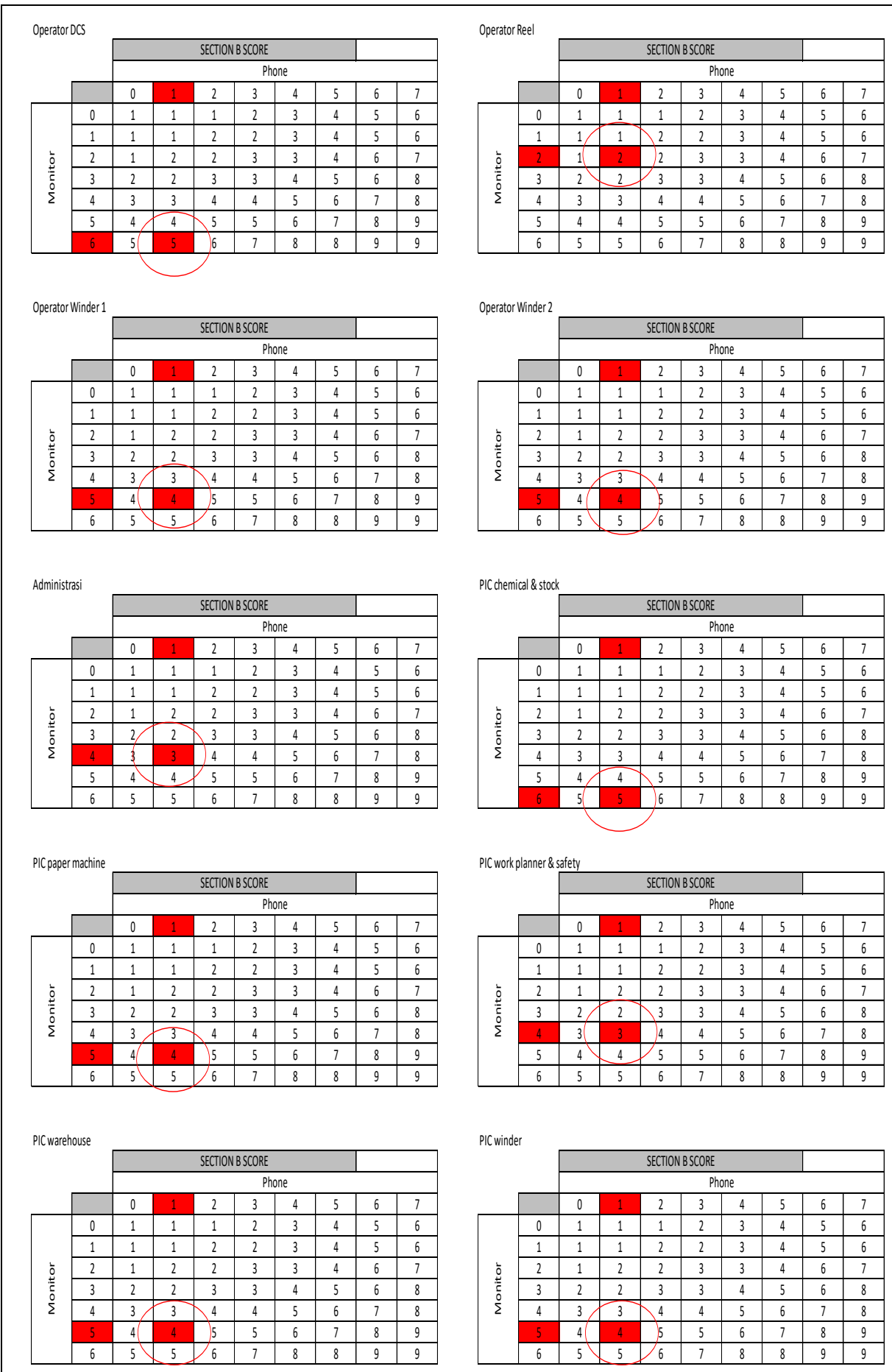

Gambar 4. Perhitungan Nilai Akhir Section B 

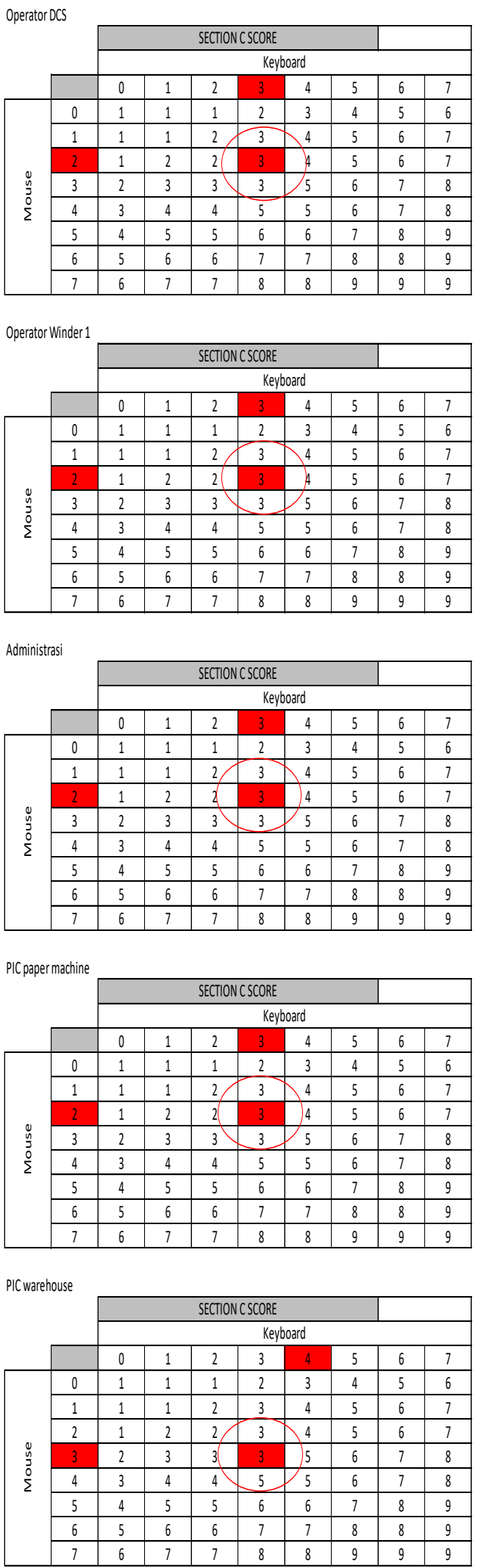
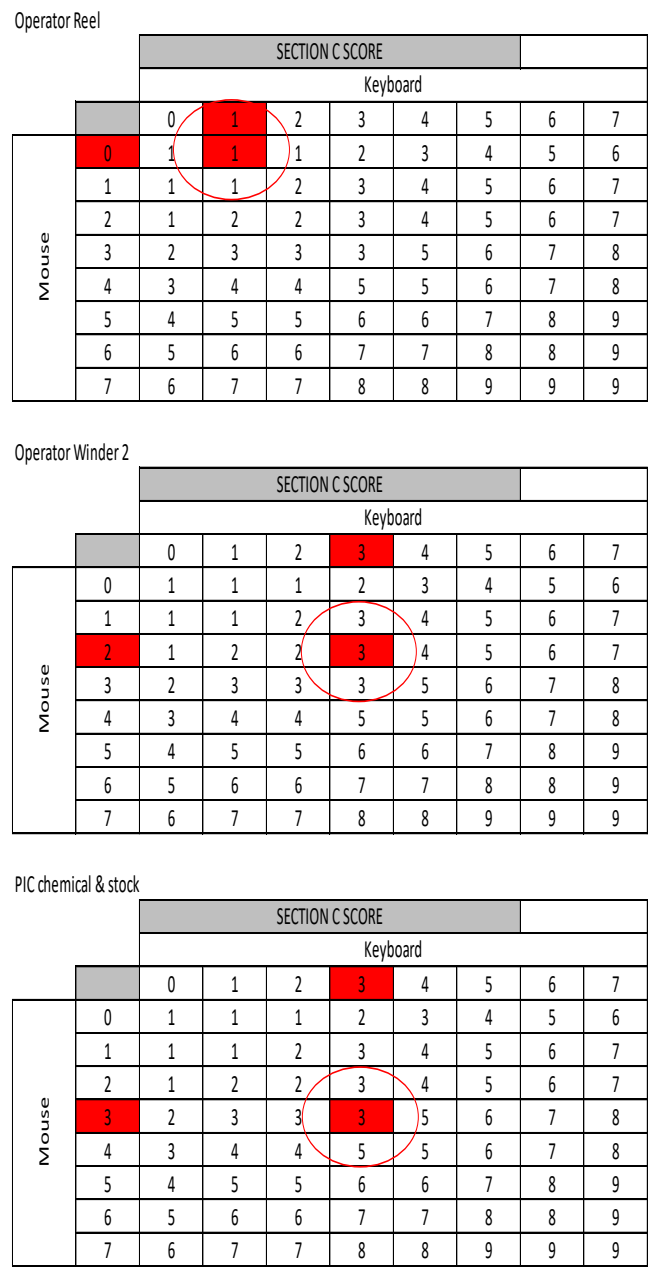

PIC work planner \& safety
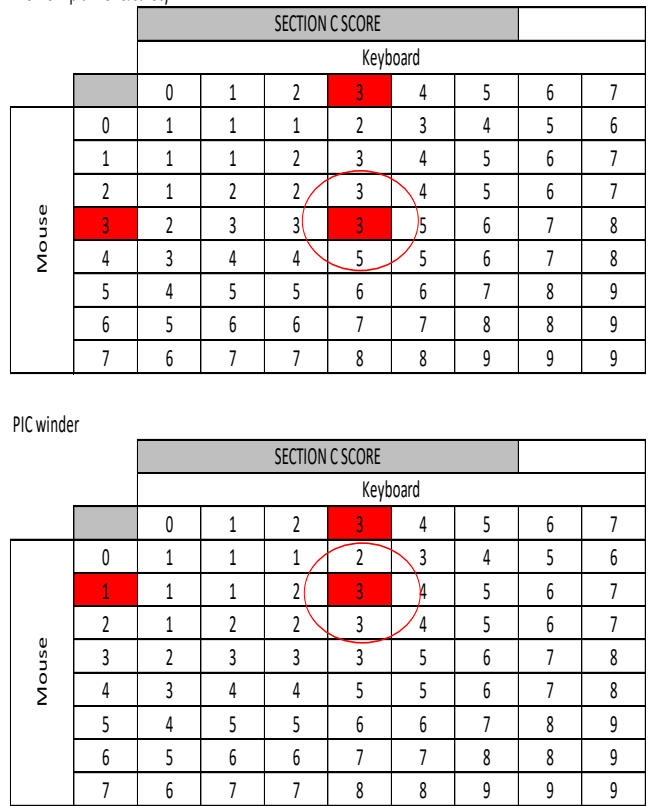

Gambar 5. Perhitungan Nilai Akhir Section C 
ISSN: 2354-6751

\subsubsection{Menentukan Nilai Monitor \& periheral score}

Penentuan nilai akhir pada tahap ini diperoleh dengan cara membandingkan nilai
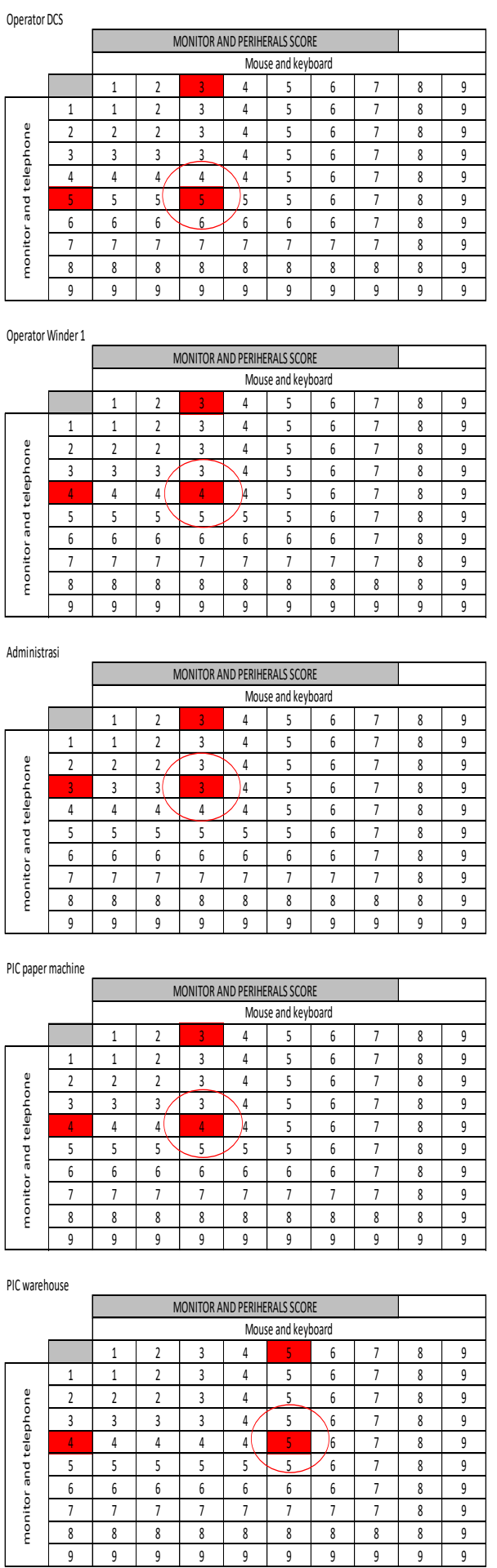

akhir yang didapat dari section $\mathrm{B}$ dan section $\mathrm{C}$ menggunakan $\log$ up table. Berikut adalah penentuan nilai akhir terhadap 10 pekerja kantor pada departemen produksi.
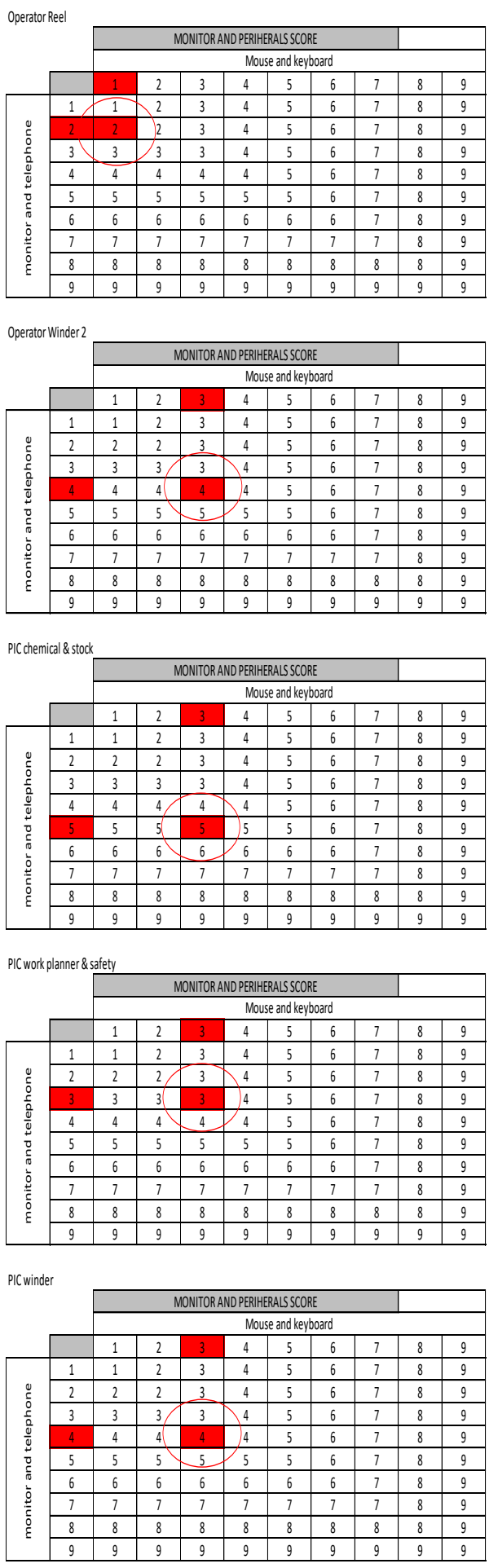

Gambar 6. Perhitungan Nilai Akhir Monitor \& Periherals 
ISSN: 2354-6751

\subsubsection{Menentukan Nilai skor akhir menggunakan metode ROSA}

Menentukan nilai akhir ROSA yaitu dengan cara membandingkan antara nilai akhir kursi yang telah dijumlahkan dengan lamanya durasi dengan nilai periheral menggunakan log up table. Gambar 5 menunjukkan tahapan penentuan akhir terhadap 10 pekerja kantor di departemen produksi.

\subsubsection{Klasifikasi Tingkat Resiko}

Setelah mendapatkan hasil akhir melalui beberapa tahapan tersebut, maka dilakukan tahapan klasifikasi resiko berdasarkan nilai akhir tersebut. Nilai tersebut menentukan apakah postur kerja yang dialami 10 pekerja kantor di departemen produksi tersebut beresiko atau tidak. Pada nilai akhir ROSA akan diperoleh nilai yang berkisar antara 1 sampai 10. Apabila nilai akhir yang diperoleh lebih besar dari 5 maka dianggap beresiko tinggi dan harus dilakukan pengkajian lebih lanjut pada tempat kerja yang bersangkutan (Sonne dkk.,2012). Tabel 9 menunjukkan klasifikasi nilai akhir terhadap 10 pekerja kantor di departemen produksi.
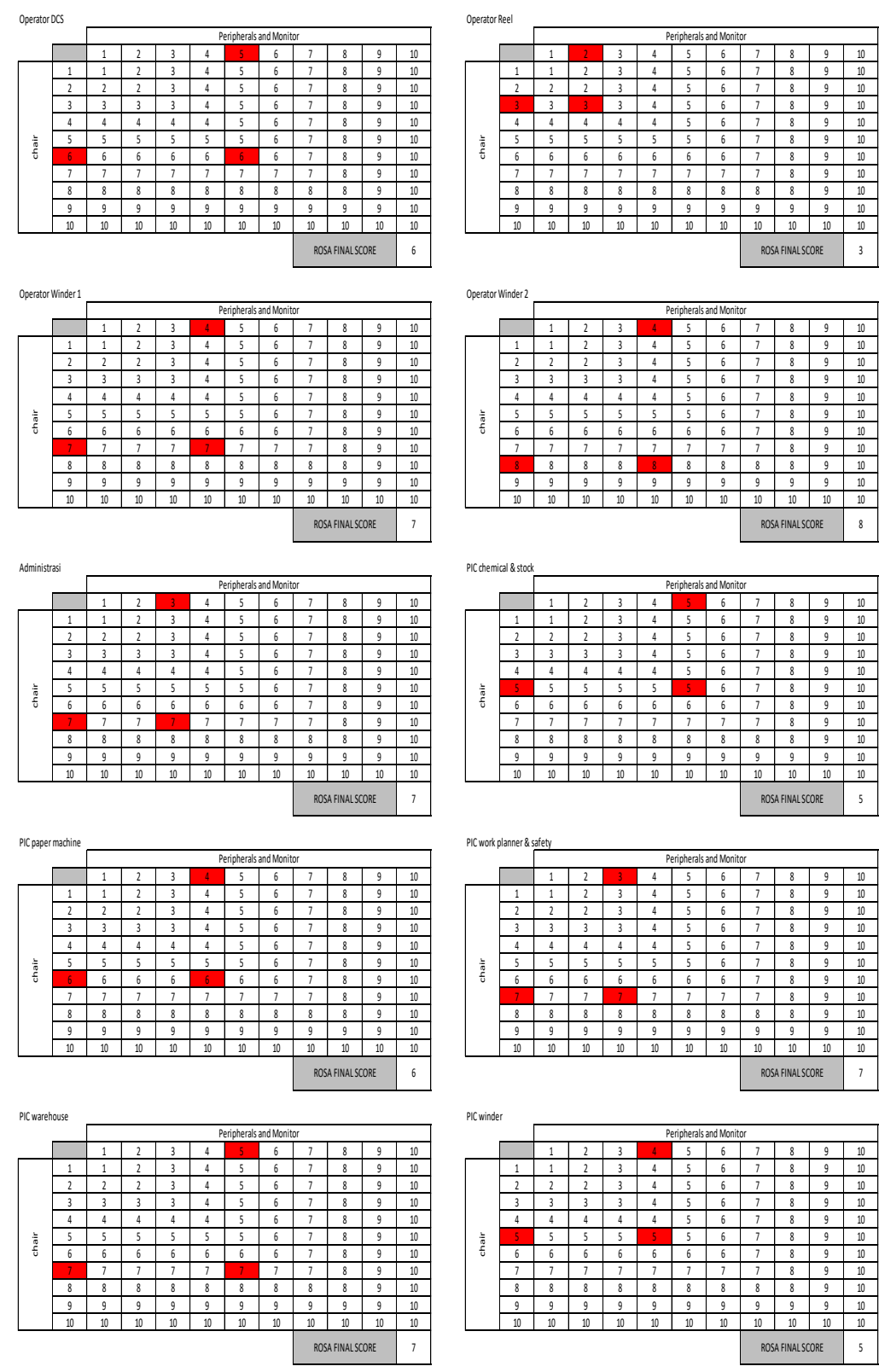

Gambar 7. Perhitungan Nilai Akhir ROSA 
Tabel 9.

Hasil Akhir Penilaian Dengan Metode ROSA

\begin{tabular}{clcc}
\hline No & \multicolumn{1}{c}{ Pekerja } & Nilai & $\begin{array}{c}\text { Tingkat } \\
\text { resiko }\end{array}$ \\
\hline 1 & DCS operator & 6 & beresiko \\
2 & Reel operator & 3 & aman \\
3 & Winder 1 Operator & 7 & beresiko \\
4 & Winder 2 Operator & 8 & beresiko \\
5 & Administrasi production & 7 & beresiko \\
6 & PIC chemical \& stock & 5 & aman \\
7 & PIC paper machine & 6 & beresiko \\
8 & PIC work planner \& safety & 7 & beresiko \\
9 & PIC warehouse & 7 & beresiko \\
10 & PIC winder & 5 & aman \\
\hline
\end{tabular}

\section{Simpulan}

Dari penelitian yang telah dilakukan maka dapat disimpulkan bahwa:

1. Keluhan tertinggi yang dirasakan oleh pekerja kantor produksi di departemen produksi paper machine 6 yaitu pada

\section{Daftar Pustaka}

[1] Habiyoga, Andre. (2016). Analisis Postur Kerja Karyawan Kantor Menggunakan Metode Rapid Office Strain Assesment (ROSA) Pada PT. Universal Tekno Reksajaya Plant Pekanbaru. Universitas Muhammadiyah Riau.

[2] Loria, Desindah. (2017). Hubungan Postur Kerja Dengan Keluhan Musculoskeletal Disorder Pada Perawat Instalasi Rawat Inap RSUD MOELOEK. Universitas Lampung.

[3] Rosma Hani Damayanti, Irwan Iftadi, Rahmaniya Dwi Astuti, (2014). Analisis punggung, pantat, pinggang, paha dan pergelangan kaki.

2. Penilaian postur kerja dengan metode ROSA menunjukkab bahwa 7 pekerja kantor beresiko tinggi dan harus dikaji lanjut, dari analisa tersebut diperoleh:

a. Operator DCS memperoleh nilai 6 artinya beresiko.

b. Reel operator memperoleh nilai 3 artinya aman.

c. Winder 1 operator memperoleh nilai 7 artinya beresiko

d. Winder 2 operator memperoleh nilai 8 artinya beresiko.

e. Administrasi production memperoleh nilai 7 artinya beresiko.

f. PIC chemical \& stock memperoleh nilai 5 artinya aman.

g. PIC paper machine memperoleh nilai 6 artinya beresiko.

h. PIC work planner \& safety memperoleh nilai 7 artinya beresiko.

i. PIC warehouse memperoleh nilai 7 artinya beresiko.

j. PIC winder memperoleh nilai 5 artinya masih aman.

Postur kerja pada PT. XYZ menggunakan Metode ROSA (Rapid Office Strain Assesment). Universitas Negeri Semarang.

[4] Sonne, M.W.L., Villalta, D.L., and Andrews, D.M, (2012). Development and Evaluation of an Office Ergonomic Risk Checklist: The Rapid Office Strain Assessment (ROSA). Applied Ergonomics 43(1), 98-108.

[5] Zen, Zayyinul Hayati (2014). Perancangan Alat Material Handling Dengan Menggunakan Pendekatan Biomekanika dan Postur Kerja pada Bagian Pengepakan Pupuk di CV. Bukit Raya Laendrys Bukittinggi, Universitas Muhammadiyah Riau 